\title{
A comparative study between infertile males and patients with Turner syndrome to determine the influence of sex chromosome mosaicism and the breakpoints of structurally abnormal $Y$ chromosomes on phenotypic sex
}

\author{
C R Quilter, N Nathwani, G S Conway, R Stanhope, D Ralph, G Bahadur, P Serhal, \\ K Taylor, J D A Delhanty
}

J Med Genet 2002;39:e80(http://www.jmedgenet.com/cgi/content/full/39/12/e80)

$\mathrm{T}$ he Y chromosome is important for male development as it contains the sex determining gene $S R Y^{1}$ and many spermatogenesis genes. ${ }^{2}$ Structural abnormalities of the $\mathrm{Y}$ chromosome include rings, deletions, inversions, and dicentrics. ${ }^{34}$ These types of abnormalities are common in infertile males $(1.5 \%)$, especially those with azoospermia. ${ }^{56}$ However, such rearrangements are unstable and an additional $45, X$ cell line is frequently present. ${ }^{3}$ The $45, X$ cell line has been shown to influence phenotypic sex so that these chromosome constitutions may also be found in patients with ambiguous genitalia and in female patients with gonadal dysgenesis and Turner syndrome. ${ }^{4}$ In fact, from cytogenetic studies about 4-6.2\% of female Turner patients show Y chromosome mosaicism $^{8-10}$ irrespective of the presence of $S R Y .^{41112}$

Mosaicism varies widely between tissues and accurate interpretation depends on the number of cells examined and the number and types of tissues studied. ${ }^{1314}$ It has been reported that phenotypic sex is strongly influenced by the percentage and distribution of Y chromosome containing cells in the gonads. ${ }^{15}{ }^{16}$ However, studies on gonadal tissue are hindered by the fact that it is rarely available for analysis and alternative, more easily accessible tissue is usually studied.

It has also been suggested that the structure of the Y chromosome may indirectly affect phenotypic sex. The repetitive sequences at the euchromatin/heterochromatin boundary of the $\mathrm{Y}$ chromosome long arm are thought to have an important stabilising role and loss of this region loses this effect, resulting in mosaicism with a $45, \mathrm{X}$ cell line. ${ }^{17}$ In dicentrics, which are the most common abnormality of the Y chromosome, ${ }^{3}$ it has been suggested that the position of the $\mathrm{q}$ arm breakpoint in dicentric Yp chromosomes can influence Y chromosome stability. The more proximal the long arm breakpoint, the greater the instability of the dicentric Yp chromosome which results in a higher percentage of $45, X$ cells and a sex phenotype which is more likely to be female. ${ }^{18}$

In this study, we have used a combination of $G$ banded cytogenetic analysis and FISH to compare levels of sex chromosome mosaicism in different tissues from infertile males and female Turner patients, with a similar mosaic karyotype. FISH and PCR were also used to characterise deletion breakpoints of abnormal Y chromosomes to see whether they were related to the stability of the Y chromosome and therefore indirectly influenced phenotypic sex through levels of $45, \mathrm{X}$ mosaicism.

\section{MATERIALS AND METHODS}

Subjects

All patients were referred to the Clinical Cytogenetics Unit, University College London Hospital (UCLH) either from the Departments of Endocrinology or Uro-nephrology or the

\section{Key points}

- The $Y$ chromosome is important for male development as it contains the sex determining gene SRY and many spermatogenesis genes. Structural abnormalities of the $Y$ chromosome include rings, deletions, inversions, and dicentrics.

- These types of abnormalities are common in infertile males $(1.5 \%)$, especially those with azoospermia. However, such rearrangements are unstable and an additional $45, X$ cell line is frequently present.

- The $45, X$ cell line has been shown to influence phenotypic sex so that these chromosome constitutions may also be found in patients with ambiguous genitalia and in female patients with gonadal dysgenesis and Turner syndrome. In fact, from cytogenetic studies, about $4-6.2 \%$ of female Turner patients show Y chromosome mosaicism, irrespective of the presence of SRY.

- In this study we have used a combination of $G$ banded cytogenetic analysis and FISH to compare levels of sex chromosome mosaicism in different tissues from infertile males and female Turner patients, with a similar mosaic karyotype. We aimed to establish the influence of sex chromosome mosaicism on resulting phenotypic sex

Assisted Conception Unit, University College London Hospitals Trust. The three infertile males (M75, M99, and M103) had azoospermia and were identified as part of a study of 103 infertile males ${ }^{19}$ and the three Turner syndrome patients (CS, NT, HE) were identified during a previous study of 54 Turner patients. ${ }^{20}$ Peripheral lymphocytes were obtained from all patients, gonadal tissue from Turner patients CS and NT, and buccal cells from Turner patient HE and infertile male M103. The clinical and gonadal features of all patients are summarised in table 1 (patient HE was an adult Turner patient and details of her paediatric phenotype were not available).

\section{Cytogenetic methods}

Cytogenetic results from PHA stimulated blood lymphocytes from all patients and from the gonadal tissue of patient CS are reported elsewhere. ${ }^{1920}$ In this study, metaphases were additionally obtained from the gonadal tissue of patient NT and were stained by a GTL banding method, using standard techniques. One hundred metaphase spreads were analysed from each patient, which should detect 3\% mosaicism with $95 \%$ confidence. ${ }^{13}$ 
Table 1 Clinical and gonadal features recorded for each patient

\begin{tabular}{|c|c|c|c|c|c|c|}
\hline & \multicolumn{6}{|c|}{ Patients } \\
\hline & M75 & M103 & M99 & NT & CS & $\mathrm{HE}$ \\
\hline \multicolumn{7}{|l|}{ Clinical features } \\
\hline Short stature & + & - & - & + & + & + \\
\hline Hyperconvex nails & - & - & - & + & - & NR \\
\hline Low posterior hairline & - & - & - & + & + & NR \\
\hline Broad chest/widely spaced nipples & - & - & - & + & + & NR \\
\hline Cubitus valgus & - & - & - & + & - & NR \\
\hline High arched palate & - & - & - & - & + & NR \\
\hline Low prominent ears & - & - & - & + & - & NR \\
\hline Pigmented naevus & + & - & - & - & - & NR \\
\hline Duplex kidney & - & - & - & - & + & NR \\
\hline Webbed/short neck & - & - & - & - & + & NR \\
\hline Ear infections & - & - & - & + & - & NR \\
\hline Coarctation of the aorta & + & - & - & - & - & NR \\
\hline Oedema & - & - & - & + & - & NR \\
\hline \multicolumn{7}{|l|}{ Gonadal features } \\
\hline Bilateral streak gonads & NA & NA & NA & + & - & + \\
\hline Ovo-testis/streak gonad & NA & NA & NA & - & + & - \\
\hline Gonadoblastoma & - & - & - & - & + & - \\
\hline History of undescended testis & + & - & - & NA & NA & NA \\
\hline Mullerian remnant & + & - & - & NA & NA & NA \\
\hline Azoospermia & + & + & + & NA & NA & NA \\
\hline
\end{tabular}

Table 2 Locus, deletion interval, size of product, and annealing temperature of each STS from PCR multiplexes V-VIII and single primer pair PCR

\begin{tabular}{|c|c|c|c|c|c|c|}
\hline PCR & STS & Locus & $\begin{array}{l}\text { Deletion } \\
\text { interval }\end{array}$ & $\begin{array}{l}\text { Size of product } \\
\text { (bp) }\end{array}$ & $\operatorname{Ta}\left({ }^{\circ} \mathrm{C}\right)$ & Reference \\
\hline \multirow[t]{2}{*}{ MV } & sY95 & DYS280 & $5 \mathrm{H}$ & 303 & 62 & 30 \\
\hline & sY100 & DYS196 & 514 & 111 & & 30 \\
\hline \multirow[t]{3}{*}{$\mathrm{MVI}$} & sY115 & DYS207 & $5 M 3$ & 115 & 62 & 30 \\
\hline & sY 128 & DYS2 19 & $5 Q 3$ & 228 & & 30 \\
\hline & sY134 & DYS224 & $6 \mathrm{~A} 4$ & 301 & & 30 \\
\hline \multirow[t]{2}{*}{ MVII } & sY106 & DYS2O2 & $5 K 2$ & 231 & 58 & 30 \\
\hline & sY113 & DYS205 & $5 M 1$ & 290 & & 30 \\
\hline \multirow[t]{2}{*}{ MVIII } & sY118 & DYS2 10 & $5 M 3$ & 218 & 62 & 30 \\
\hline & sY126 & DYS2 17 & $5 Q 1$ & 323 & & 30 \\
\hline Single & sY122 & DYS2 13 & $5 \mathrm{~N} 4$ & 201 & 62 & 30 \\
\hline
\end{tabular}

\section{FISH}

Results of FISH with biotinylated cosmid 378E (prepared at the Lawrence Livermore National Library $)^{21}$ are reported elsewhere for infertile males ${ }^{19}$ and Turner syndrome patient ${ }^{20}$ and were used to identify $S R Y$ and the adjacent part of the pseudoautosomal region (PARl).

In this study, additional FISH with a commercial X/Y subtelomeric probe set (Cytocell -CY29/c8.2/1) was carried out according to the manufacturer's instructions to characterise the Yp breakpoints of dicentric Yq chromosomes. FISH was also used to study sex chromosome mosaicism on interphase cells using a commercial $\alpha$-satellite probe mix (Vysis) for chromosomes 18, X, and Y (CEP 18 Spectrum Aqua, CEP X Spectrum Green, and CEP Y Spectrum Orange). Peripheral lymphocytes were analysed from all patients, cultured gonadal tissue from Turner patients CS and NT, and buccal cells from Turner patient HE and infertile male M75. The 18 $\alpha$-satellite probe was only viewed where necessary to establish ploidy. Slides of peripheral lymphocytes and gonadal tissue were prepared by standard methods and buccal cells according to a method described elsewhere. ${ }^{22}$ The FISH method used and visualisation has been previously outlined. ${ }^{23}$

For metaphase analysis, a minimum of five metaphases containing the structurally abnormal Y chromosome were examined for each probe. For interphase FISH analysis of peripheral lymphocytes and gonadal tissue, 500 counts were made on good quality non-overlapping cells and over 50 cells were scored for buccal tissue. Peripheral lymphocytes were also scored from two normal male sperm donors, used as controls.

\section{PCR}

DNA was extracted from $5 \mathrm{ml}$ of peripheral blood using a previously described method ${ }^{24}$ or a commercial kit (QIAmp). Both groups of patients have been analysed by PCR as part of larger studies to screen for Y chromosome microdeletions in infertile males $^{19}$ and to detect the presence of Y sequences in Turner syndrome..$^{20}$ In this study, additional primers were used in four multiplex reactions and one single primer reaction to characterise Yq breakpoints and details of these primers are summarised in table 2. The PCR method was carried out as previously described. ${ }^{19}$ All PCR assays were carried out at least twice, and control reactions were also performed with DNA extracted from a normal male, from a normal female, and water.

\section{RESULTS}

\section{Cytogenetics}

The cytogenetic results are summarised in table 3. The percentage of metaphases with a Y chromosome ranged from $36-95 \%$ in infertile male patients and from $3-26 \%$ in Turner patients. The percentage of cells with a Y chromosome was 
Table 3 G banded cytogenetic results from the peripheral lymphocytes of all patients and the gonadal tissue of patients NT and CS

\begin{tabular}{llll}
\hline Patient & Tissue & Karyotype & Reference \\
\hline M75 & Lymphocytes & $45, X[64] / 46, X, \operatorname{idic}(Y)(q 11.2)[36]$ & 19 \\
M103 & Lymphocytes & $45, X[6] / 46, X, \operatorname{idic}(Y)(q 11.2)[94]$ & 19 \\
M99 & Lymphocytes & $45, X[5] / 46, X, \operatorname{idic}(Y)(p 11.3)[95]$ & 19 \\
NT & Lymphocytes & $45, X[97] / 46, X, \operatorname{idic}(Y)(q 11.2)[3]$ & 20 \\
& Gonadal & $45, X[94] / 46, X, \operatorname{idic}(Y)(q 11.2)[6]$ & - \\
CS & Lymphocytes & $45, X, \operatorname{inv}(5)(p 14 q 11.2)[94] / 47, X, \operatorname{idic}(Y)(p 11.3)+$ & 20 \\
& idic(Y)(p1 1.3), inv(5)(p1 (pq11.2)[6] & 20 \\
& Gonadal & $45, X, \operatorname{inv}(5)(p 14 q 11.2)[74] / 47, X, \operatorname{idic}(Y)(p 11.3)+$ & \\
& & $\operatorname{idic}(Y)(p 11.3), \operatorname{inv}(5)(p 14 q 11.2)[25] / 46, X, \operatorname{idic}(Y)(p 11.3)$, & \\
HE & inv(5)(p14q11.2)[1] & 20 \\
\hline
\end{tabular}

Table 4 Interphase FISH results from all tissues from both sets of patients

\begin{tabular}{|c|c|c|c|c|c|c|c|c|}
\hline \multirow[b]{2}{*}{ Patients } & \multicolumn{7}{|c|}{ Signal number (\%) } & \multirow[b]{2}{*}{ No of cells } \\
\hline & $\mathrm{Y}$ & $x$ & $X Y$ & $x x$ & $X X Y$ & $\mathrm{XYY}$ & XYYYY & \\
\hline Control male 1 & & $1(0.2)$ & $499(99.8)$ & & & & & 500 \\
\hline Control male 2 & & & $496(99.2)$ & $2(0.4)$ & & $2(0.4)$ & & 500 \\
\hline M75 & & $212(42.4)$ & & $1(0.2)$ & & $286(57.2)$ & $1(0.2)$ & 500 \\
\hline M99 & & $39(7.8)$ & & & & $459(91.8)$ & $2(0.4)$ & 500 \\
\hline M103 & & $52(10.4)$ & & & & $447(89.4)$ & $1(0.2)$ & 500 \\
\hline $\mathrm{M103} \mathrm{b}$ & & & & & & $54(80.6)$ & $12(17.9)$ & 67 \\
\hline NT & & $476(95.2)$ & & $1(0.2)$ & & $23(4.6)$ & & 500 \\
\hline NT g & & $454(90.8)$ & & $4(0.8)$ & $1(0.2)$ & $41(8.2)$ & & 500 \\
\hline CS & $1(0.2)$ & $433(86.6)$ & & & & $4(0.8)$ & $62(12.4)$ & 500 \\
\hline $\mathrm{CSg}$ & & $296(64.4)$ & & $2(0.4)$ & $1(0.2)$ & $13(2.8)$ & $148(32)$ & 500 \\
\hline $\mathrm{HE}$ & & $464(90.8)$ & $46(9.2)$ & & & & & 500 \\
\hline $\mathrm{HE} \mathrm{b}$ & & $80(80)$ & $20(20)$ & & & & & 100 \\
\hline
\end{tabular}

$\mathrm{g}=$ gonadal tissue, $\mathrm{b}=$ buccal mucosa, rest=lymphocytes, percentages in brackets.

found to be higher in the gonadal tissue than the peripheral lymphocytes for both Turner patients, but was still less than $30 \%$. One metaphase out of 100 analysed from the gonadal tissue of Turner patient CS was found to have only one idic(Yq) chromosome compared to the 25 metaphases with two. FISH analysis confirmed the validity of this one cell.

\section{PCR}

Previous cytogenetic, FISH, and PCR analyses have shown that infertile males M75 and M103 and Turner patient NT have a cell line containing an $\operatorname{idic}(Y p)$ chromosome, and Turner patient HE has a cell line containing a del(Yq) chromosome. ${ }^{19} 20$ In this study, PCR with additional primer pairs was used to refine the $Y$ chromosome $\mathrm{q}$ arm breakpoints. These results are summarised as part of fig 1 . Sequence tagged sites (STSs) have previously been assigned to Y chromosome deletion intervals. ${ }^{25}$ Patients M75, M103, and NT were found to have breakpoints in Yq between Y chromosome STS sY118 (5M3) which was present and sYl22 (5N4) which was absent in all three patients. Patient HE was found to have a more proximal Yq breakpoint between Y chromosome STSs sY100 (5I4) and sY106 (5K2)

\section{FISH}

\section{Metaphase analysis}

Our previous studies indicated that both Turner patient CS and infertile male M99 have a cell line containing an idic(Yq) chromosomes with two copies of $S R Y .{ }^{19}{ }^{20}$ In this study the Yp subtelomeric probe (CY29) was found to be absent from the dicentric Yq chromosomes in both patients. The Yq subtelomeric probe (c8.2/1) was present at either end of the abnormal $\mathrm{Y}$ chromosomes and served as a control. These results are summarised as part of fig l. The Yp breakpoint in both cases was therefore found to be between cosmid $378 \mathrm{E}$ specific for
$S R Y$ and the adjacent part of PARI and the Yp subtelomeric probe (CY29). SRY and the Yp subtelomeric probe are 2.5 Mb and 100-300 kb from the Yp telomere, respectively.

\section{Interphase analysis}

Interphase FISH analysis of both groups of patients and controls are summarised in table 4 . The percentage of interphase cells from peripheral lymphocytes with a Y signal ranged from $57.7-91.8 \%$ in infertile males and from $4.6-12.4 \%$ in Turner patients. Results from buccal and gonadal tissues gave higher levels of Y chromosome mosaicism than in the blood in all cases, but no higher than 35\% for the Turner patients. Results from the control males indicated that any result found in less than approximately $1 \%$ of cells was not significant; therefore the majority of patients were found to have two cell lines, a $45, \mathrm{X}$ cell line and a cell line with one $\mathrm{X}$ and an abnormal $\mathrm{Y}$ chromosome.

Infertile male patient M75, one exception, was found to have an additional cell line in the buccal cells with one $\mathrm{X}$ and four $\mathrm{Y}$ signals, thought to correspond to a 47,X,idic(Yp) + idic(Yp) cell line. In the lymphocytes only $1 / 500(0.2 \%)$ cells had been observed with this fluorescent pattern, which had been considered insignificant, but in view of the buccal cell results may represent this cell line at a very low level of mosaicism in the blood. In addition, a 45,X cell line was not recorded from the buccal mucosa of this patient but may have gone undetected owing to fewer cells being available for analysis. In the blood, Turner patient CS was found to have a second cell line with two idic(Yq) chromosomes. However, the FISH results from the gonadal tissue of this patient confirmed the presence of a third cell line with only one dicentric Yq, which was also seen in one $\mathrm{G}$ banded metaphase analysed from this tissue. Only 4/500 $(0.8 \%)$ of interphase cells from the peripheral lymphocytes gave 


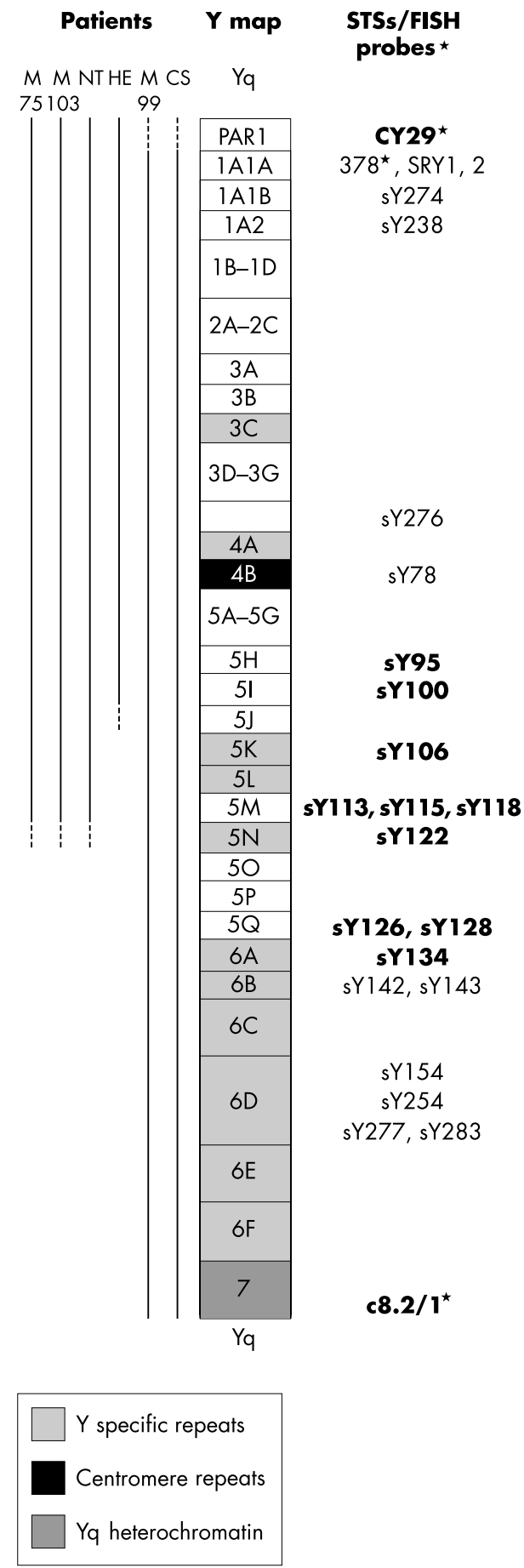

Figure $1 Y$ chromosome map based on that described previously. ${ }^{25}{ }^{31}$ Lines representing abnormal $Y$ chromosomes are shown to the left of the $Y$ chromosome map where a solid line represents $Y$ sequences present, a broken line represents the region of the breakpoint, and a blank represents the extent of the deletion. Primers and FISH probes are shown to the right of the $Y$ map with those used in this study in bold, others were used elsewhere..$^{19} 20$

this result but again may represent the cell line at a very low level of mosaicism in the blood.

\section{DISCUSSION}

This study aimed to establish the influence of sex chromosome mosaicism on resulting phenotypic sex. Peripheral lymphocytes were examined for mosaicism in all patients because of their ease of accessibility and culture. Using standard cytogenetic methods, the levels of $Y$ bearing cells were 36-95\% in infertile males and $3-8 \%$ in Turner patients. These levels were similar when this tissue was examined by interphase FISH analysis, finding $57.7-91.8 \%$ and $4.6-12.4 \%$ respectively. Much higher percentages of Y bearing cells were therefore found in the male patients. Results from the blood of patient M75 gave the lowest percentage of $\mathrm{Y}$ bearing cells seen in a phenotypic male, with $36 \%$ after cytogenetic analysis and $57.7 \%$ after interphase FISH analysis. The latter probably gave a more accurate assessment of mosaicism levels owing to the greater number of cells examined. The higher percentage of 45,X bearing cells in M75 compared to the other males may explain the presence of Turner features in this patient but suggests that they were not at a high enough level to result in a female phenotype.

Blood is derived from the mesoderm but does not necessarily reflect the germ cells, which arise extragonadally in connection with the endoderm. ${ }^{15}$ Comparison of different tissues in this study confirmed that there are variations in levels of mosaicism, with Y bearing cells being higher in other tissues than in the blood.

It was possible to examine gonadal tissue from two Turner patients (NT and CS) since gonadectomies had been performed as a preventative measure against the development of gonadoblastoma. The levels of Y bearing cells were seen to be at least twice as high in the gonads compared to the blood, with higher percentages again being found with interphase FISH. An additional cell line was also found after examination of the gonadal tissue of patient CS, presumably formed as a result of mitotic non-disjunction of the unstable dicentric $\mathrm{Y}$ chromosomes.

Gonadal tissue was not available from the other patients in this study. Where possible, buccal cells were examined as a second tissue because they were easily obtained and derive from a different cell lineage, the ectoderm. For Turner patient $\mathrm{HE}$, the percentage of Y bearing cells was found to be twice as high after examination of the buccal mucosa cells, suggesting that there were significant differences in levels of mosaicism between tissues in this patient. The investigation of buccal mucosa also led to the discovery of an additional cell line in infertile male M103.

Overall, our mosaicism studies suggested that analysis of the blood gives a guide to levels of mosaicism in relation to phenotypic sex even though it is not necessarily identical to mosaicism in the gonads. In our patients, much higher percentages of $Y$ bearing cells were found in the phenotypic males. It appeared that the percentage of $45, \mathrm{X}$ cells in the female Turner patients resulted in the $S R Y$ gene being expressed below a critical threshold in the gonadal ridge of these females so that development along the male pathway did not occur. In order to predict the percentage of $45, \mathrm{X}$ cells required for a patient to be phenotypically female rather than male, analysis of multiple tissues from many more cases will be necessary. In general, to obtain an accurate picture of mosaicism in terms of percentages and number of cell lines, analysis of more than one tissue from different cell lineages is required. Interphase FISH analysis appeared to be a simple method of analysing larger numbers of cells and could also be used to analyse cells from non-dividing tissues such as the buccal mucosa.

Our study also confirmed that dicentrics are a common structural rearrangement of the $\mathrm{Y}$ chromosome in mosaic patients. Minimal areas of euchromatin appeared to be deleted, which has also been reported previously. ${ }^{27}$ We also examined the breakpoints of structurally abnormal Y chromosomes to see whether they had any effect on chromosomal stability, hence influencing levels of mosaicism and resulting phenotypic sex. Infertile male M99 and Turner patient CS both had dicentric Yq chromosomes and were found to have breakpoints between cosmid $378 \mathrm{E}$ and the Yp subtelomeric probe (CY29). However, the percentage of cells with the dicentric Yq 
chromosome was markedly higher in male patient M99 and it appears that the position of the $p$ arm breakpoint did not influence the stability of the dicentric Yq chromosome. The breakpoint is similar to that found in two Turner syndrome patients with dicentric $\mathrm{Yq}$ chromosomes described previously, ${ }^{27}$ confirming that there are common Y chromosome $\mathrm{p}$ arm breakpoints susceptible to the formation of dicentric Yq chromosomes. These breakpoints appear to be within PARl, which is where recombination occurs between the sex chromosomes, making it a hotspot for breakage and reunion.

It has been proposed that dicentric Yp chromosomes are less stable the more proximal the $\mathrm{q}$ arm breakpoint, resulting in higher levels of $45, X$ cells and a possible female phenotype. ${ }^{17}{ }^{18}$ In our study, the $\mathrm{q}$ arm breakpoint of the dicentric Yp chromosomes was between STS sY1 18 (5M3) and sY122 (5N4) in patients of both sexes, in distal interval 5. Again the cell lines containing the dicentric Y chromosome were at much higher levels in the phenotypic male patients, which suggested that the position of the $\mathrm{q}$ arm breakpoint in dicentric Yp chromosomes also did not appear to influence $\mathrm{Y}$ chromosome stability. The breakpoint in our patients is similar to a previously described case of a Turner patient with a dicentric Yp chromosome in which the breakpoint was determined to be between $\mathrm{Y}$ chromosome intervals $5 \mathrm{~J}$ and $5 \mathrm{Q} .{ }^{27}$ Other studies of Turner patients with a cell line containing a dicentric Yp chromosome have reported a q arm breakpoint in what appears to be a common region of distal Y chromosome deletion interval 6, close to the heterochromatic block. ${ }^{12}{ }^{27}$ Both this position and the breakpoints found in our patients occur in the $\mathrm{Y}$ specific repeat regions of $\mathrm{Yq}^{25}$ However, the breakpoint seen in Turner patient HE, who had a terminal deletion of the $\mathrm{Y}$ chromosome $\mathrm{q}$ arm was in a more proximal region of $\mathrm{Yq}$ outside the $\mathrm{Y}$ specific repeats. We therefore propose that multiple areas of $\mathrm{Y}$ specific repeat sequences along the $\mathrm{Y}$ chromosome $\mathrm{q}$ arm are susceptible to breakage and reunion and in these cases formation of dicentrics. This is substantiated by reports that common Yq microdeletions found in infertile males are bounded by $\mathrm{Y}$ repeat regions, thought to serve as substrates for homologous recombination..$^{28}$

\section{ACKNOWLEDGEMENTS}

We would like to thank the patients for participating in this research and their clinicians for cooperating and making this study possible. We are also grateful to all members of Clinical Cytogenetics, formerly of the Galton Laboratory, University College London, for their help with the processing of samples. The experiments were undertaken with the approval of the ethics committee of the University College London Hospitals Trust.

\section{Authors' affiliations}

C R Quilter, K Taylor, The Galton Laboratory, University College London, Wolfson House, 4 Stephenson Way, London NWI 2HE, UK N Nathwani, G S Conway, R Stanhope, Department of Endocrinology, University College London Hospitals Trust, London WCl, UK

D Ralph, Department of Uro-nephrology, University College London Hospitals Trust, London WCI, UK

G Bahadur, J D A Delhanty, Department of Obstetrics and Gynaecology, University College London Hospitals Trust, London WC1, UK

P Serhal, Assisted Conception Unit, University College London Hospitals Trust, London WCl, UK

Correspondence to $\operatorname{Dr}$ C R Quilter, Department of Pathology, University of Cambridge, Tennis Court Road, Cambridge CB2 1QP, UK;

crq20@cam.ac.uk

\section{REFERENCES}

1 Sinclair AH, Berta P, Palmer MS, Hawkins JR, Griffiths BL, Smith M, Foster JW, Frischauf A, Lovell-Badge R, Goodfellow PN. A gene from the human sex-determining region encodes a protein with homology to a conserved DNA-binding motif. Nature 1990;346:240-4.

2 Lahn BT, Page DC. Functional coherence of the human Y chromosome. Science 1997;78:675-9.
3 Hsu LYF. Phenotype/karyotype correlations of $Y$ chromosome aneuploidy with emphasis on structural aberrations in postnatally diagnosed cases. Am J Med Genet 1994;53:108-40

4 Tuck-Muller CM, Chen H, Martinez JE, Shen CLS Kusyk C, Batisa DAS, Bhatnagar YM, Dowling E, Wertelecki W. Isodicentric Y chromosome: cytogenetic, molecular and clinical studies and review of the literature. Hum Genet 1995;96:1 19-29.

5 Bourrouillou G, Dastugue N, Colombies P. Chromosome studies in 925 infertile males with a sperm count below 10 million/ml. Hum Genet 1985;71:366-7.

6 Van Assche E, Boudelle M, Tournaye H, Joris H, Verheyen G, Devroey $P, V a n$ Steirteghem A, Liebaers I. Cytogenetics of infertile men. Genetic and assisted human conception. Hum Reprod 1996;11:1-26.

7 Teraoka M, Narahara K, Yokoyama Y, Tsuji K, Kikkawa K, Ito S Koyama K, Seino Y. 45,X/46,X,idic(Yq) mosaicism: clinical, cytogenetic, and molecular studies in four individuals. Am J Med Genet 1998:78:424-8

8 Ostrer H, Clayton CM. Y chromosome mosaicism in 45,X Turner syndrome. Am J Med Genet 1989;34:294-6.

9 Jacobs PA, Betts PR, Cockwell AE, Crolla JA, Mackenzie M, Robinson DO, Youings SA. A cytogenetic and molecular reappraisal of patients with Turner's syndrome. Ann Hum Genet 1990;54:209-23

10 Jacobs P, Dalton P, James R, Mosse K, Power M, Robinson D, Skuse D. Turner syndrome: a cytogenetic and molecular study. Ann Hum Genet 1997;61:471-83

11 Morava E, Hermann R, Czako M, Soltesz G, Kosztolanyi G. Isodicentric $Y$ chromosome in an Ullrich-Turner patient without virilization. Am J Med Genet 2000;91:99-101.

12 Godoy Assumpcao J, Hackel C, Marques-de-Faria AP, Palandi de Mello M. Molecular mapping of an idic(Yp) chromosome in an Ullrich-Turner patient. Am J Med Genet 2000;91:95-8.

13 Hook EB. Exclusion of chromosomal mosaicism: Tables of $90 \%, 95 \%$, and $99 \%$ confidence limits and comments on use. Am J Hum Genet 1977;29:94-7.

14 Procter SE, Watt JL, Lloyd DJ, Duffy P. Problems of detecting mosaicism in skin. A case of trisomy 8 mosaicism illustrating the advantage of in situ tissue culture. Clin Genet 1984;25:273-7.

15 Reddy KS, Sulcova V. Pathogenetics of $45, X / 46, X Y$ gonadal mosaicism Cytogenet Cell Genet 1998;82:52-7

16 Kelly TE, Franko JB, Rogol A, Golden WL. Discordant phenotypes and 45,X/46,X,idic(Y). J Med Genet 1998:35:862-4

17 Jakubowski L, Jeziorowska A, Constantinou M, Kaluzewski B. Molecular analysis of $Y$ chromosome long arm structural instability in patients with gonadal dysfunction. Clin Genet 2000;57:291-5.

18 Stuppia L, Calabrese G, Guanciali Franchi P, Mingarelli R, Morizio E, Sabatino G, Palka G. Molecular studies in three patients with isodicentric Y chromosome. Hum Genet 1996;98:691-5.

19 Quilter CR, Svennivik EC, Serhal P, Ralph D, Bahadur G, Stanhope R, Sutterlin M, Delhanty JDA, Taylor K. A cytogenetic and $Y$ chromosome microdeletion screen of a group of unselected infertile males. (In preparation.)

20 Quilter CR, Taylor K, Conway GS, Nathwani N, Delhanty JDA Cytogenetic and molecular investigations of $Y$ chromosome sequences and their role in Turner syndrome. Ann Hum Genet 1998;62:99-106.

21 Taylor K, Hornigold N, Conway D, Williams D, Ulinowski Z, Agochiya $M$, Fattorini $P$, de Jong $P$, Little PF, Wolfe J. Mapping the human $Y$ chromosome by finger printing cosmid clones. Genome Res 1996;6:235-48.

22 Tomczak EZ, Punnett HH. An improved method for chromosome enumeration using fluorescent in situ hybridization of buccal epithelium. Ass Genet Technol 1998;24:6-7.

23 Quilter CR, Holman S, Al-Hamadi RMYA, Theodorides D, Hastings RJ Delhanty JDA. Aneuploidy screening in direct chorionic villus samples by fluorescence in situ hybridisation: the use of commercial probes in a clinical setting. Br J Obstet Gynaecol 2001;108:215-18.

24 Lahiri DK, Nurnberger Jl. A rapid non-enzymatic method for the preparation of HMW DNA from blood for RFLP studies. Nucleic Acids Res 1991;19:5444.

25 Foote S, Vollrath D, Hilton A, Page DC. The human Y chromosome: overlapping DNA clones spanning the euchromatin region. Science 1992;258:60-6.

26 Reijo R, Alagappan RK, Patrizio P, Page DC. Severe oligozoospermia factor gene on $Y$ chromosome. Lancet 1996;347:1290-3

27 Robinson DO, Dalton P, Jacobs PA, Mosse K, Power MM, Skuse DH Crolla JA. A molecular and FISH analysis of structurally abnormal $Y$ chromosomes in patients with Turner syndrome. J Med Genet 1999;36:279-84

28 Blanco P, Shlumukova M, Sargent CA, Jobling MA, Affara N, Hurles ME. Divergent outcomes of intrachromosomal recombination on the human Y chromosome: male infertility and recurrent polymorphism. $J$ Med Genet 2000;37:752-8.

29 Kuroda-Kawaguchi T, Skaletsky H, Brown LG, Minx PJ, Cordum H S, Waterson RH, Wilson R K, Silber S, Oates R, Rozen S, Page DC. The AZFc region of the $Y$ chromosome features massive palindromes and uniform recurrent deletions in infertile men. Nat Genet 2001;29:279-86.

30 Vollrath D, Foote S, Hilton A, Brown LG, Beer-Romero P, Bogan JS Page DC. The human $Y$ chromosome: a 43-interval map based on naturally occurring deletions. Science 1992;258:52-9.

31 Vergnaud G, Page DC, Simmler MC, Brown L, Rouyer F, Noel B, Botstein $D$, de la Chapelle A, Weissenbach J. A deletion map of the human $Y$ chromosome based on DNA hybridization. Am J Hum Genet 1986;38: 109-24. 